\title{
Da transmição hídrica a culicidiana: a febre amarela na sociedade de medicina e cirurgia de São Paulo
}

Luiz Antônio Teixeira FIOCRUZ - Casa de Oswaldo Cruz

\section{RESUMO}

Este artigo trata das discussões sobre as formas de propagação da febre amarela ocorrida entre os anos de 1896 e 1900, na Sociedade de Medicina e Cirurgia de São Paulo, concentrando-se na figura do importante médico da época, Luis Pereira Barreto. Discutimos os principais argumentos defendidos pelos esculápios envolvidos nas controvérsias e mostra a contribuição da Sociedade no processo de aceitação da teoria de transmissão culicidiana da doença no Brasil.

Palavras-chave: saúde pública; febre amarela; transmissão culicidiana.

\begin{abstract}
This paper deals with the discussions about the ways of yellow fever transmission that took place between the years of 1896 and 1900 in the Sociedade de Medicina e Cirurgia de São Paulo, and centers around the figure of one of the most important physicians of the period, Luis Pereira Barreto. It discusses the main arguments defended by the physicians involved in the controversies and shows the contribution of that society in the process of the acceptance of the theory of culicidean transmission of the disease in Brazil. Keywords: public health; yellow fever; culicidean transmission.
\end{abstract}

Na última década do século XIX, a febre amarela foi o tema principal dos debates médicos no país. Suas formas de propagação e meios de prevenção ocuparam grande parte dos esculápios voltados para a saúde pública nos nossos principais centros urbanos. Em São Paulo não seria diferente. $\mathrm{Na}$ inexistência de uma faculdade que centralizasse os debates, a questão foi intensamente discutida na Sociedade de Medicina e Cirurgia de São Paulo.

Neste trabalho, são discutidos os principais argumentos defendidos pelos médicos envolvidos nos debates sobre o tema que ocorreram na Sociedade, procurando mostrar a contribuição desta instituição ao proces- 
so de aceitação da teoria de transmissão culicidiana da doença no Brasil. O principal elemento da análise é fornecido pela produção intelectual de Luiz Pereira Barreto sobre a doença. Primeiro diretor da Sociedade de Medicina e Cirurgia e figura de destaque no campo médico da época, Pereira Barreto teve um papel importante nessas discussões, pois seu trabalho ajudou na criação de um consenso sobre a transmissão culicidiana da doença no país.

O tema em questão é objeto de diversos textos analíticos. Ultimamente vem sendo revisto pelo pesquisador Jaime Benchimol, que em seu último trabalho elaborou um painel sobre a história da doença, centrando sua pesquisa na figura do médico Domingos José Freire. Seu estudo foi a principal fonte secundária utilizada neste capítulo ${ }^{1}$. A pesquisadora paulista Marta Almeida também se voltou para a temática em dissertação sobre a trajetória de Emílio Ribas na saúde pública paulista. Seu estudo mais recente sobre o tema discute as experiências de ratificação da teoria culicidiana da doença elaboradas pela saúde pública paulista, entre 1902 e $1903^{2}$.

Este trabalho toma como base a noção de campo criada por Pierre Bourdieu. Com ele, considera-se que o campo científico constitui um espaço relacional de luta pelo monopólio da autoridade científica. Tal perspectiva permite ultrapassar avaliações retrospectivas simplistas, relacionadas a erros e acertos na construção de argumentos científicos, em prol de uma análise que leve em conta que a legitimação de uma determinada teoria provém da força relativa dos grupos ou indivíduos a ela relacionados ${ }^{3}$.

\section{A DOENÇA}

Entre as últimas décadas do século XIX e os primeiros anos do século XX, a febre amarela foi o flagelo que mais preocupou os médicos voltados para a saúde pública, mostrando-se como a principal moléstia epidêmica que grassava no país. A cada ano suas epidemias ceifavam milhares de vidas em nossas maiores cidades. Além disso, representavam um entrave à continuidade do processo de importação de mão de obra e dificultavam o desenvolvimento do comércio com os países europeus, elementos vitais à manutenção do modelo econômico naquele período.

A doença era conhecida desde longa data no Brasil. Aqui chegou durante o último quartel do século XVII, provavelmente trazida das Antilhas, onde grassava desde a época dos descobrimentos. Em 1685 houve epidemias em Olinda e em outras cidades do interior de Pernambuco; no ano seguinte, outro grande surto na Bahia. Não há notícias de outras epidemias no período colonial. No entanto, em 1849 ela voltou à Bahia, de onde se alastrou para diversas regiões litorâneas, transformando-se no 
maior pesadelo dos governantes pelo estigma que causava em relação aos nossos portos. A primeira grande epidemia do Sudeste foi em 1849, no Rio de Janeiro. A partir dessa época, a doença visitaria constantemente a capital federal, atacando grande parte de sua população e, principalmente, os imigrantes. Não é sem motivo que a cidade ficaria conhecida como o "túmulo dos estrangeiros".

Em São Paulo, a febre amarela surgiu na cidade de Santos, porta de entrada dos imigrantes que vinham trabalhar nas lavouras cafeeiras. A partir de 1850, a cidade foi atingida por constantes surtos da doença que, a cada verão, vinha com os tripulantes dos navios recém-chegados, alastrando-se a partir da região portuária. Como a doença não chegou rapidamente à região central do Estado, mantendo-se na baixada litorânea que se interpõe entre o mar e o altiplano interno, imaginava-se que ela era exclusiva das zonas baixas, não levando perigo aos habitantes do interior, resguardados pela Serra do Mar.

No ano de 1889, uma forte epidemia se instalou na cidade de Santos, indo bater às portas de grande parte do Oeste Paulista e chegando a Campinas, capital agrícola da província e seu segundo maior centro. A partir desse momento, a "princesinha do Oeste", como a chamavam à época, seria atingida por sucessivas epidemias em 1889, 1890, 1892, 1896 e 1897. De Campinas esses surtos se alastravam pelas demais cidades do Oeste, gerando preocupações à medida que colocavam em risco a produção cafeeira. A disseminação da doença pelo interior do Estado jogou por terra a antiga noção, de que a febre amarela era um mal adstrito ao litoral, incapaz de subir a Serra do Mar. Entre 1898 e 1904, todos os anos surgiram epidemias da doença em cidades do Oeste Paulista 5 .

Até meados do século XIX, várias teorias eram utilizadas para explicar o surgimento da doença e embasar as formas de combatê-la. Na primeira metade da década de 1870, ainda havia fortes divergências sobre os meios de propagação da enfermidade; para uns, ela era contagiosa, ou seja, passada diretamente de pessoa a pessoa; para outros, tratava-se de um mal transmissível ou infeccioso, que necessitava de um agente que o transportasse do doente a uma pessoa sã. No entanto, era consenso que a febre amarela constituía uma doença que se originava de emanações pútridas - os miasmas. Para explicar seu aparecimento, os médicos apelavam para diversos fatores topográficos, atmosféricos, de saneamento, etc. A partir do estudo de estatísticas e da observação de diversos aspectos ambientais, relacionavam a incidência das epidemias de febre amarela - que geralmente se davam no verão - ao calor, à quantidade de chuvas, aos níveis de ozônio na atmosfera, à umidade proveniente dos pântanos - considerados um dos principais focos de exalação dos miasmas - e aos mor- 
ros que dificultavam a circulação dos ventos capazes de purificar o ar, o principal veículo de disseminação dos eflúvios miasmáticos. Ladeados por engenheiros, químicos e outros profissionais de campos correlatos, os médicos higienistas voltavam-se para a intervenção nos aspectos urbanísticos: o ar confinado nas habitações coletivas, nas fábricas, nas ruas estreitas; a influência corruptora dos matadouros, cemitérios, valas, esgotos e a água nem sempre vinda de fontes puras eram os principais focos de sua atenção. Assim, as formas de combater o mal se voltavam para medidas de reorganização urbana e normatização de vários aspectos da vida cotidiana. No campo das terapêuticas individuais, vigiam as antigas fórmulas da medicina oitocentista, baseadas em xaropes, sangrias e outras medidas.

No último quartel do século XIX, o desenvolvimento dos conhecimentos sobre os micróbios alteraria profundamente esse quadro. Os trabalhos de Pasteur, Koch e seus seguidores sobre a atuação dos microorganismos na transmissão das doenças abririam caminho para o estudo da febre amarela sob o paradigma da microbiologia. No Brasil, as pesquisas microbiológicas sobre a doença ganharam fôlego no início da década de 1880, na capital federal. Ainda neste ano, o então professor de química orgânica e biologia da Faculdade de Medicina do Rio de Janeiro, Domin220 gos Freire, propunha que a doença era causada por microorganismos, e que injeções hipodérmicas de salicilato de sódio - ácido sintético similar ao acetilsalicílico - curavam o mal já instalado. Em 1883, João Batista Lacerda, médico, chefe da Seção de Antropologia, Zoologia e Anatomia do Museu Nacional, afirmava que a febre amarela era causada por um organismo vegetal encontrado nas vísceras de suas vítimas. Ainda nesse ano, Domingos Freire voltou à cena, anunciando a descoberta do microorganismo causador da febre amarela: o Cryptococcus xanthogenicus, uma espécie de alga que contaminava as águas, o ar, a terra, os alimentos frios, os cemitérios e os hospitais. Anunciada a sua descoberta, ele partiu para a elaboração de uma vacina contra a doença, que começou a aplicar experimentalmente ainda em $1883 .^{6}$

A década de 1890 também foi pródiga em estudos visando à identificação do micróbio da febre amarela. Pesquisadores brasileiros e estrangeiros engalfinharam-se em violentas controvérsias sobre a paternidade da descoberta de seu agente causador. Em meados da década de 1890, não havia consenso sobre o assunto, e os trabalhos de Domingos Freire - que dez anos antes pareciam ter tido maior aceitação - encontravam-se agora desgastados, sendo aceitos com reservas por um diminuto grupo de médicos. Por outro lado, floresciam as discussões sobre a forma de propagação da doença. Sem o caráter experimental observado nas pesquisas 
para a identificação do germe, este tipo de investigação de cunho epidemiológico baseava-se em observações precedentes sobre as formas de propagação das epidemias da doença.

O conhecimento sobre a forma de transmissão da febre amarela deve-se ao médico cubano Carlos Finlay que, a partir de 1881, publicou artigos invocando o mosquito como o verdadeiro transmissor da doença. No entanto, naquele momento, suas idéias não tiveram eco na comunidade científica. Somente em 1900 os trabalhos experimentais de uma comissão médica americana em Cuba trouxeram à tona a hipótese do cubano, permitindo a colocação em prática de medidas de profilaxia específicas, que acabaram por dar fim às grandes epidemias urbanas da doença nos países tropicais.

A questão da etiologia do mal permaneceu obscura por mais algum tempo. Somente em 1927, quando o desenvolvimento das ciências biomédicas possibilitou maiores conhecimentos sobre os vírus, ela seria esclarecida por médicos da Fundação Rockefeller que, na África ocidental, elaboraram pesquisa de inoculação em macacos. No ano seguinte conseguiu-se a atenuação do vírus nos laboratórios do Instituto Pasteur de Paris; finalmente, em 1937, a Fundação Rockefeller começou a produzir vacinas em larga escala contra a doença.

Hoje, aceita-se que a febre amarela é uma infecção de origem viral, causada por um arbovirus do gênero Flavirus, em sua forma silvestre. Ele tem como principal hospedeiro vertebrado o sagüi, também infectando outros pequenos roedores. A partir do reservatório natural, a doença é transmitida pelo mosquito Aedes aegypti, que se reproduz principalmente em coleções de águas domiciliares e peridomiciliares, propagando a doença rapidamente em regiões urbanas. É uma doença aterrorizante pela rapidez e abrangência de sua propagação e pela intensidade dos sintomas, caracterizados pelo quadro grave de insuficiência renal e hepática, que pode levar rapidamente à morte. Depois da picada por mosquito infectado, existe um curto período de incubação que pode durar de três a seis dias. Sua manifestação é rápida, dá-se com o surgimento de fortes cefaléias, dores musculares, calafrios e outros sintomas de infecção aguda. A evolução do mal leva a vômitos e outros sintomas advindos da degeneração do aparelho digestivo; icterícia, que causa uma coloração amarela na pele dos doentes; hemorragias e diminuição da secreção urinária.

\section{O FÓRUM DE DISCUSSÃO}

Em 1895, ainda antes da febre amarela ultrapassar os limites da região litorânea do Estado de São Paulo, foi criada a Sociedade de Medici- 
na e Cirurgia de São Paulo, instituição que, em pouco tempo, transformou-se no mais importante espaço de discussão científica sobre a febre amarela no Estado. O surgimento da sociedade foi fruto da expansão do campo médico da capital paulista, ocorrido nas duas últimas décadas do século XIX. Neste momento, multiplicaram-se o número de consultórios, farmácias e hospitais na cidade e surgiram as primeiras iniciativas de organização profissional dos médicos. De forma análoga a outros setores, o processo de organização e expansão do campo médico paulista foi fruto do desenvolvimento sócio-econômico da cidade e, de forma mais geral, do Estado, que teve por base a expansão da lavoura cafeeira e a conseqüente entrada de um grande contingente de imigrantes no Estado ${ }^{8}$.

Durante a década de 1880, surgiriam as primeiras iniciativas de organização do campo médico paulista, com a tentativa de elaboração de um congresso médico, o surgimento efêmero de uma revista médica e de uma sociedade, mas foi na década seguinte que as iniciativas nesse sentido começaram a vingar. Em 1892, já sob o governo republicano, São Paulo remodelou seus serviços de saúde, através de uma reforma sanitária que deu origem ao Serviço Sanitário Estadual. A gênese deste processo se relaciona às más condições sanitárias reinantes nas zonas urbanas e rurais e à falta de serviços médico sanitários, que ameaçavam a manutenção do processo de desenvolvimento econômico baseado na importação de mãode-obra. Seu resultado pode ser visto como um marco na trajetória de expansão do campo médico, pois determinou a criação de diversas instituições ligadas tanto à prática médica, como ao desenvolvimento dos conhecimentos científicos neste campo. A criação do Serviço Sanitário de São Paulo pode ser vista também como um marco no campo da saúde pública, pois o raio de ação dos novos serviços de saúde distavam, em muito, das poucas atividades de fiscalização da medicina e combate à varíola efetuadas pelas agências estaduais que o precederam. Além disso, o conjunto de laboratórios - ou institutos, como passaram a ser chamados - criados com a reforma foram os pilares do Serviço Sanitário. Os Institutos: Bacteriológico - por mais de quinze anos dirigido pelo bacteriologista Adolpho Lutz - Vacinogênico, Bromatológico, Farmacêutico e, posteriormente, o Butantan, tiveram importante atuação no diagnóstico de doenças epidêmicas e na elaboração de produtos profiláticos e terapêuticos para o combate aos principais males que atingiam o Estado. Seu trabalho foi fundamental para a melhoria das condições de saúde no Estado e, principalmente, na capital.

Mas voltemos ao nosso ponto focal. A primeira tentativa de se criar uma Sociedade de Medicina em São Paulo data de 1888 e não obteve sucesso; somente em 1895 a Sociedade de Medicina e Cirurgia foi efetiva- 
mente criada. Os artífices da nova instituição foram o dr. Sérgio Meira, que também foi o primeiro diretor do Serviço Sanitário de São Paulo, Mathias Valladão e Luiz Pereira Barreto. Este último, eminente figura paulista: médico, destacado filósofo positivista e político do Partido Republicano, se tornou o primeiro presidente da sociedade, mais tarde recebendo a honraria de presidente perpétuo da instituição. A primeira reunião preparatória para a criação da entidade aconteceu em 24 de fevereiro de 1895, congregando vários expoentes da classe médica da capital. Neste momento, Pereira Barreto foi escolhido, por aclamação, presidente da nova instituição. Em março deu-se a inauguração da sociedade, que passou a funcionar em uma sala cedida pela Faculdade de Direito do Largo São Francisco, logo transferindo-se para novas instalações na Rua São Bento.

De forma bastante ampla, observamos que, tal qual outras entidades do mesmo tipo, a sociedade tinha o objetivo de reunir o corpo médico de São Paulo em torno de um órgão responsável pela manutenção dos seus interesses profissionais, divulgar entre seus pares as mais novas aquisições do patrimônio científico da área médica, e potencializar o desenvolvimento dos saberes biomédicos pelas discussões entre seus sócios. Em seu plenário, discutiam-se todas as questões tidas como importantes para a classe médica: a etiologia das diversas doenças que atingiam o Estado, a estipulação de honorários justos, a regulamentação do exercício profissional, a condenação do charlatanismo, etc. Desde a sua fundação, a Sociedade publicava um boletim com suas discussões, trabalhos apresentados e atas de suas reuniões. Por motivos de ordem econômica, este deixou de existir em 1898, sendo que, no mesmo ano, os resumos das reuniões passaram a ser publicados na recém - fundada Revista Médica de São Paulo.

Numa avaliação retrospectiva, podemos assegurar que em sua primeira década de atividades, a Sociedade teve um importante papel no cenário científico, médico-profissional e de saúde pública no Estado. De suas discussões brotaram diversos estudos e pareceres sobre doenças e outros problemas de agravo à saúde existentes em São Paulo. Em relação aos objetivos corporativos, a instituição defendeu, até judicialmente, os interesses dos médicos do Estado. Teve ainda importante papel no terreno das atividades médico-assistenciais através da Policlínica, instituição criada no ano seguinte à sua fundação, sob seu patrocínio. Num momento de incipiência organizativa do campo médico do Estado, as atividades da Sociedade foram importantes no processo de sua institucionalização, suprindo a falta de outras instituições, como uma faculdade médica que nucleasse os debates do campo e aproximasse seus membros. 


\section{A FEBRE AMARELA NA SOCIEDADE DE MEDICINA}

No ano da fundação da Sociedade de Medicina, a febre amarela era objeto das discussões que mais mobilizavam o campo médico do Rio de Janeiro, com fortes repercussões em São Paulo. No entanto, estas discussões tiveram pouco eco na Sociedade, ficando mais a cargo dos médicos inteiramente voltados para a microbiologia, concentrados no Instituto Bacteriológico de São Paulo.

Em 1896 a situação se modificou em virtude da forte epidemia que teve início na Cidade de Campinas. O surgimento dos primeiros casos, no início do ano, Fez soar o alarme da possibilidade de uma grande epidemia, pois esta se manifestavam sempre no mesmo período do ano; principiando em janeiro ou fevereiro, propagava-se em março até atingir o clímax em abril. Começava então a declinar por volta de maio e extinguia-se em junho, no inverno. Já em meio à epidemia, Luis Pereira Barreto propôs que a Sociedade discutisse e adotasse uma moção aconselhando medidas para interromper a sua fatídica marcha. Sua proposta tinha como base a possibilidade de a doença ser transmitida pela água, o que, a seu ver, era uma conclusão logicamente observável pelo cruzamento das informações sobre a freqüência de epidemias naquela cidade e a ampliação da distribuição de água encanada. Seguia-se à justificativa científica um conjunto de medidas que objetivava sanear os mananciais existentes e ampliar a oferta de água encanada para a população.

Considerando que, no verão de 1889 e no de 1890 , quando a população de Campinas servia-se exclusivamente da água de poços, foi a cidade atacada por duas largas e mortíferas epidemias; considerando que terminados os trabalhos de encanamento e esgotos, em princípios de 1891, e fornecida à população água potável em abundância, tomada de um manancial não poluído cessou a epidemia, não havendo mais um só caso da moléstia reinante; considerando que, no verão de 1892, devido ao fato de voltar a população ao uso da água de poços, por causa do incidente ocorrido no principal reservatório, reapareceu a epidemia com o mesmo caráter de gravidade e só cessou depois que a população passou a fazer uso da água encanada; considerando que destes fatos ressalta, com toda a evidência, a convicção que não se pode imaginar uma experiência feita em melhores condições, porquanto por duas vezes tivemos ali a prova e a contraprova, surgindo a epidemia com o uso da água poluída e cessando ela no momento em que cessou o uso da água incriminada; considerando que por toda a parte (...) o modo de propagação da epidemia se deixa claramente vincular ao fato da contaminação da água potável (...) A Sociedade de Medicina e Cirurgia de São Paulo resolve declarar poluída a 
água de Campinas e aconselhar a quem de direito medidas, as mais urgentes a tomar $(\ldots)^{9}$.

Em busca de aliados para a sua causa, Pereira Barreto utilizou o expediente mais caro e mais criticado entre os acadêmicos: foi para a grande imprensa reafirmar as suas idéias. Em 6 de maio iniciou a publicação de uma série de artigos no Commercio de São Paulo. Sob o título de Epidemiologia, ele reabilitou antigos escritos seus elaborados a partir de 1889, que pareciam ganhar nova vida com as evidências observadas em Campinas.

Pereira Barreto declarava que sua hipótese se prendia a evidências advindas do cruzamento de dados sobre o surgimento de epidemias da doença no Estado, com os de distribuição de água encanada, apresentando dados estatísticos que procuravam relacionar estas duas variáveis. No entanto, acreditamos que um outro fator estava na base do seu modo de pensar. A partir de 1892, começaram a surgir vários surtos de cólera na cidade. Fragmentos de uma pandemia que varreu grande parte do Ocidente entre 1881 e 1896, estes surtos acabariam por se transformar em uma epidemia de grandes proporções, que atingiu o eixo Estado do Rio - São Paulo entre 1894 e 1895. Doença infecciosa de grande letalidade, o cólera vinha juntar-se à febre tifóide, que em constantes surtos atacava o Estado e, principalmente, a cidade de São Paulo. Ambas eram sabidamente de veiculação hídrica e formavam o quadro do qual Pereira Barreto extraía a analogia com a febre amarela, transformando a água na responsável única pela transmissão da doença. Contágio direto, falta de arejamento, poluição dos ares, transmissão mista, nada disso a ele importava, somente a água. A capital do Estado, por exemplo, era tida como imune à enfermidade, em virtude da qualidade da água - a seu ver, excelente oriunda da serra da Cantareira.

Como vemos, Pereira Barreto construía seu argumento no frágil solo desta única variável, em contraposição a todos os outros possíveis meios de propagação visualizados na época. Esta forma de pensar rapidamente atraiu um grande número de opositores, visto existirem defensores das várias possibilidades de disseminação da doença. Além disso, sua posição política de cacique do Partido Republicano fazia com que normalmente chovessem críticas às suas posições públicas. No dia seguinte ao aparecimento de seu primeiro artigo no Commercio de São Paulo, o Estado de São Paulo começou a publicar - também sob o título de epidemiologia - uma série de editoriais contrários à sua posição. De início tratava-se de ressentimentos pela inclusão ou não de alguns nomes de políticos, no rol de elogios feitos aos responsáveis pela construção do excelente sistema de dis- 
tribuição de água da cidade. Logo, as críticas passaram a se dirigir às suas postulações técnico-científicas, deixando de ser apresentadas como editoriais, e tornando-se matérias assinadas, às vezes por anônimos ou pelo médico Bernardo de Magalhães. Este, numa longa série de artigos, procurava mostrar que, embora a teoria hídrica fosse pertinente, a febre amarela era também contagiosa. A seu ver, a relação entre o deslocamento das pessoas entre as cidades e o aparecimento da doença mostrava esse fato ${ }^{10}$.

Mas deixemos os jornais e voltemos à Sociedade de Medicina. Também lá a proposição de Pereira Barreto ensejou o aparecimento de novos posicionamentos sobre o tema. A grande discussão que sua proposta gerou fez com que as três sessões subseqüentes à sua apresentação fossem inteiramente voltadas para a questão da febre amarela. Em 9, 15 e 22 de abril, os sócios da casa se defrontaram em longuíssimas discussões sobre a propagação da doença, apresentando em seguida artigos consolidando suas posições. No desenrolar da controvérsia, Pereira Barreto foi perdendo terreno na sua argumentação, pois a maioria de seus opositores acreditava em formas mistas de transmissão, relacionando o aparecimento da doença em vários lugares e momentos às mais diversas ocorrências.

Os artigos publicados nos boletins mostram a diversidade de opiniões sobre o tema. Mello Barreto escreveu defendendo a transmissão hídrica acrescida da transmissão aérea. Em seguida, foi a vez de Evaristo da Veiga que, em uma série de artigos, tratou dos sintomas da doença e postulou sua contagiosidade. Luiz Augusto de Paula, médico da Repartição de Higiene de Campinas, defendeu a não-exclusividade da forma de contaminação: ar, água, solo poderiam ser veículos de propagação da doença. A seu ver, o importante era que o mal tinha um caráter de infecção domiciliar, com o germe se irradiando a partir das casas contaminadas. Theodoro Reichert também escreveu defendendo o contágio, e postulando a desinfecção rigorosa dos domicílios, o isolamento completo dos doentes, a assepsia dos cadáveres e sepulturas, o estabelecimento de sistemas de distribuição de água potável para as regiões atingidas, e a plantação de árvores de eucalipto ao redor das cidades contaminadas. Dentre os outros participantes da discussão, somente Bitencourt Rodrigues era favorável à exclusividade da teoria hídrica. Ainda mostraram-se contrários a essa possibilidade Tibério de Almeida, Carlos Botelho, Miranda de Azevedo, Hora de Magalhães, Odilon Goulart, Theodureto Nascimento, Sérgio Meira, Matias Valadão, Bernardo de Magalhães, Esteves de Assis, Cunha e Vasconcellos e Mello Barreto.

Em 22 de maio, a discussão foi paralisada pela impossibilidade de se alcançar um consenso. A diretoria da casa decidiu tirar o tema de sua pau- 
ta de reuniões e nomear uma comissão para estudar mais detidamente a questão. Esta seria composta por Ataliba Florence, Cândido Espinheira, Faria Rocha, Gualter Pereira e Alfredo Medeiros. Tal qual a epidemia, que ia se enfraquecendo com a chegada do inverno, as discussões também esfriaram. Escolhida a comissão, o tema deixou de ser discutido. No entanto, os membros da comissão nunca vieram a público apresentar um relatório de seus estudos.

É interessante observar que, de forma paradoxal, o momento de esvaziamento das discussões coincide com a tomada de iniciativa do executivo para reverter a situação epidêmica reinante. No final de maio, Campos Sales, então presidente do Estado, enviou ao Congresso um projeto de lei tratando do tema. Este autorizava o governo a promover a execução de obras de saneamento na capital, em Santos, Campinas e demais localidades do Estado onde reinasse a epidemia; nessas localidades, o poder estadual teria o direito de criar, desapropriar ou encampar os serviços de água e esgoto existentes. Em relação ao financiamento das obras, o projeto era draconiano e funcionava como um empréstimo compulsório. O governo do Estado bancaria a execução, que seria cobrada posteriormente dos municípios; o poder estadual tinha o direito de tomar como garantia as rendas provenientes do imposto predial e das taxas de fornecimento de água e recolhimento de esgoto dos municípios inadimplentes.

No dia seguinte ao envio do projeto ao Legislativo Estadual, o então secretário do Interior, Dino Bueno, foi à Sociedade com o objetivo de assistir às discussões sobre o tema. Fato que foi assim registrado nos anais da Sociedade:

Tal acontecimento é digno de nota especial, porque nunca compareceu as seções nenhum membro do governo nem da diretoria do Serviço Sanitário. O precedente estabelecido pelo Dr. Dino Bueno além de significar um ato de extrema cortesia e consideração para com a Sociedade de Medicina e Cirurgia, mostra que o governo do distinto cidadão Dr. Campos Sales está disposto a dar a seus atos outro cunho de orientação, porque não só na Capital federal, como nas capitais da Europa, Rio da Prata, etc., as associações científicas mereceram sempre dos bons governos todas as atenções, sendo suas decisões fielmente ouvidas, em se tratando de questões de sua competência. ${ }^{11}$

Apesar da solicitude do Executivo, o secretário não pôde assistir à sessão na qual a discussão sobre a doença mais uma vez se travaria. Por motivos desconhecidos, não houve quórum para a sua realização. Talvez os próceres da ciência médica do Estado não quisessem deixar claro ao 
Executivo que eles não tinham uma opinião consensual sobre o modo de agir em relação à questão.

De qualquer forma, o projeto de lei, elaborado no Executivo e posteriormente encampado pelo Legislativo, vinha ao encontro da formulação da maioria dos médicos, procurando garantir o fim do reinado da febre amarela pela execução de um conjunto de ações, que tinham como base a teoria da transmissão mista da doença. Assim, a drenagem do solo e a construção de redes de esgoto, a implantação ou ampliação da oferta de água encanada proveniente de fontes sabidamente puras, e as reformas urbanas necessárias - como a construção de canais de ventilação para levar ar limpo à cidade de Santos, diminuindo assim a sua umidade - eram a base do projeto de saneamento, que também procurava disciplinar ainda mais o serviço de imigração, com a construção de novos postos de quarentena para os tripulantes de embarcações provenientes de portos suspeitos de contaminação.

O desenrolar dos fatos até agora observados mostra o surgimento de um consenso sobre a transmissão mista da febre amarela e o isolamento de Pereira Barreto em sua posição de defensor intransigente da transmissão unicamente por via hídrica. No entanto, a posição por ele defendida parece ter influenciado no tipo de obras de saneamento adotadas preferencialmente pelos poderes públicos. Segundo Tellaroli Junior, antes do início da controvérsia sobre a teoria hídrica, as atividades da Diretoria do Serviço Sanitário Estadual no saneamento urbano voltavam-se exclusivamente para a melhoria da higiene pública e particular, com ações visando a ampliar a coleta de lixo, a limpeza de logradouros públicos, a fiscalização dos domicílios, etc. As iniciativas estaduais, visando à ampliação da distribuição de água encanada e da coleta de esgotos, que nos primeiros anos da década se limitavam aos municípios da capital, Santos e Campinas, tornaram-se mais freqüentes a partir de 1896, período da polêmica sobre a importância da transmissão hídrica da febre amarela.

Apesar das muitas contestações pelos médicos, fica a impressão de que o prestígio pessoal do Dr. Pereira Barreto, o impacto da teoria hídrica na opinião pública e a falta de resultados positivos com as medidas até então adotadas, voltadas exclusivamente à urbanização, à melhoria na limpeza pública e privada e ao isolamento hospitalar dos doentes, contribuíam para o incremento das obras estaduais de água e esgoto. ${ }^{12}$

\section{UM ITALIANO AGITA A SOCIEDADE}

Passados os debates sobre a transmissão hídrica, a febre amarela seria um assunto por algum tempo deixado em segundo plano na Socieda- 
de, gerando apenas alguns poucos artigos. Em 1898, a doença, por um curto período de tempo, voltaria ao centro das atenções na Sociedade. Era um ano de forte epidemia na cidade de Santos e, no meio médico, as atenções continuavam voltadas para a possibilidade de desenvolvimento de uma terapêutica contra a doença. No ano anterior, um certo dr. Caldas, de Porto Alegre, veio a público com a notícia da descoberta do soro com essa propriedade. Não tardou para que as autoridades do campo médico, lideradas por Adolpho Lutz, concluíssem pela ineficácia do produto. Mas os avanços da microbiologia, e da soroterapia em particular, faziam com que as esperanças na descoberta de um soro que curasse a doença continuassem crescentes. Foi nesse contexto que o bacteriologista italiano Giuseppe Sanarelli foi a São Carlos do Pinhal efetuar pesquisas epidemiológicas com um soro que vinha desenvolvendo. Em 1896, ele havia se instalado no Uruguai, onde dirigia o recém fundado Instituto de Higiene Experimental. Poucos meses depois de assumir a instituição, Sanarelli foi ao Rio de Janeiro recolher material para iniciar estudos sobre a febre amarela. No final de 1896, os jornais cariocas anunciavam que ele tinha descoberto o micróbio da doença, e se voltava agora para a preparação do soro curativo contra o mal. A autoridade científica já conquistada pelo cientista em virtude dos seus trabalhos anteriores sobre a febre tifóide, o interesse da colônia italiana nos trabalhos de seu patrício, e o suspense gerado pela imprensa em virtude da demora de sua conferência fizeram com que, de um momento para outro, o cientista se transformasse no centro das atenções e depositário de todas as esperanças de finalmente dar fim à doença. ${ }^{13}$

Em junho de 1897, Sanarelli finalmente apresentou sua descoberta em conferência promovida em Montevidéu. Diante do presidente da República, dos mais altos expoentes da elite uruguaia, e de delegações médicas de diversos países, ele afirmou ter conseguido isolar, em meio de cultura, um bacilo que supunha ser o causador da doença. Seus trabalhos tiveram ecos imediatos no Brasil. No Rio de Janeiro foram comentados, com entusiasmo, na Academia Nacional de Medicina e na Sociedade de Medicina e Cirurgia, onde os médicos Francisco Fajardo e Miguel Couto ratificaram com novos estudos as suas conclusões. Em São Paulo não seria diferente, pois seus trabalhos eram esperados com grande ansiedade. Adolpho Lutz, comissionado para acompanhar a conferência em Montevidéu, juntamente com o ajudante do Instituto Bacteriológico, Arthur Mendonça, foi o primeiro a tecer opiniões sobre as pesquisas do italiano. A seu ver, tudo parecia indicar que o microorganismo apresentado no Uruguai era mesmo o causador da febre amarela, mas isto não alterava em nada a situação vigente. Novas pesquisas deveriam ser realizadas para 
a elaboração de um soro ou vacina que curasse ou protegesse contra a doença. ${ }^{14}$ Arthur Mendonça também se entusiasmou com o trabalho do italiano, passando a defender suas premissas.

Oito meses depois da conferência de Montevidéu, Sanarelli foi convidado pela classe médica paulista para realizar, na cidade de São Carlos do Pinhal, novos estudos de campo sobre a doença. Sua chegada a São Paulo foi triunfal. Nos salões da Sociedade de Medicina e Cirurgia, tomados pelos mais conceituados médicos do Estado, ele foi saudado em grande estilo por Sérgio Meira que, em nome da sociedade, deu-lhe boas vindas; seu discurso terminava comparando os resultados iniciais do trabalho do cientista italiano às mais importantes descobertas médicas da época: "A difteria perpetuou o nome de Behring, a febre amarela glorificará Sanarelli através de todas as gerações futuras." 15

Depois da parte festiva, Sanarelli rumou para São Carlos, onde iniciou as inoculações experimentais de seu produto curativo. Os testes foram acompanhados por uma comissão do Estado, presidida por Silva Pinto, então diretor do Serviço Sanitário, e integrada por Adolpho Luz, Vital Brasil, Arthur Mendonça, Candido Espinheira (diretor do Hospital de Isolamento) e por seis inspetores sanitários. Os trabalhos de verificação dos resultados das inoculações foram dificultados pela falta de doentes. De 230 qualquer forma, o índice de sucesso do medicamento era muito baixo, não autorizando nenhuma inferência positiva sobre seu poder curativo. $\mathrm{O}$ fracasso da série de inoculações fez com que a comissão apresentasse um parecer que, embora aceitasse a existência e especificidade do microorganismo, punha por terra o valor do soro, afirmando que ele não apresentava atividade quando empregado em seres humanos e que, portanto, a terapêutica da febre amarela não encontrava solução na soroterapia. ${ }^{16}$

A observação da ineficácia do soro pelos pesquisadores do Bacteriológico jogou por terra a esperança de utilização do medicamento. No entanto, permaneceu a possibilidade do microorganismo identificado ser mesmo o agente causal da doença. Na Sociedade, a iniciativa terapêutica do italiano foi rapidamente esquecida sem mesmo gerar discussões sobre sua real eficácia. Por outro lado, seus trabalhos de identificação do microorganismo foram objeto de diversos debates. Para ser mais preciso, as discussões sobre a etiologia da doença, ocorridas na Sociedade entre a estadia de Sanarelli em São Paulo e a aceitação da forma de transmissão culicidiana da doença, sempre se voltavam para os seus trabalhos, criticando-os ou defendendo-os. Entre seus detratores, destacava-se Afonso Azevedo, que asseverava que o micróbio isolado por Sanarelli não tinha caracteres distintivos uniformes, era dificilmente encontrado nos doentes e produzia, quando inoculado nos animais, um quadro nosológico di- 
ferente da febre amarela. ${ }^{17} \mathrm{Na}$ defesa de seus trabalhos marcou posição o bacteriologista Arthur Mendonça. Desde sua estadia em Montevidéu, ele não pouparia esforços para defender a existência e o papel do bacilo icteróide no surgimento da doença. Mesmo depois da larga divulgação e grande aceitação da teoria culicidiana, Mendonça continuaria mantendo sua posição. De início, assegurava que as descobertas havidas em Cuba vinham confirmar os trabalhos de Sanarelli, e depois passou a desqualificar as proposições dos americanos e seus seguidores, não aceitando de forma alguma que a transmissão da doença fosse feita por mosquitos. Egresso do Instituto Bacteriológico em 1900 por divergir radicalmente de Lutz nesse aspecto, ele continuaria a defender suas posições na tribuna da Sociedade e nas páginas da Revista Médica de São Paulo, que por longo tempo comandou.

\section{DA TRANSMISSÃO HÍDRICA À CULICIDIANA}

Em 1900, a febre amarela voltou a ser discutida na Sociedade. Outra vez foi Pereira Barreto queM fez emergir a questão, com um novo artigo sobre a forma de propagação da doença. Desta feita, um de seus alvos era a nova hipótese de transmissão defendida pelo cientista do Museu Nacional do Rio de Janeiro, João Batista Lacerda, que sugeria que a difusão do bacilo icteróide de Sanarelli se dava pelo ar. Mas antes de falarmos sobre este novo trabalho, vejamos um pouco do contexto em que foi elaborado.

Como vimos, foi ainda na década de 1880 que o cubano Carlos Finlay postulou que a doença era transmitida pelo mosquito. No entanto, a teoria culicidiana demorou vinte anos para ser ratificada pelo campo médico. No Brasil, de início, poucos pesquisadores acolheram o corolário de Finlay. Em 1885, um certo professor Filogônio Lopes Untinguassú, em discussão na Academia Imperial de Medicina do Rio de Janeiro, defendeu que os mosquitos se infectavam sugando o sangue dos amarelentos, e depois contaminavam a água, que se transformava na maior fonte de transmissão da doença. Sua fala não se formalizou em artigo, ou comunicação posterior, e suas idéias não tiveram nenhuma repercussão. ${ }^{18}$ Num período em que doenças como o cólera, a febre tifóide e a tuberculose mostravam o potencial da transmissão hídrica e do contágio, a idéia da transmissão culicidiana não teve muito espaço. Somente depois que o inglês Ronald Ross descobriu que o plasmódio da malária era transportado por mosquitos do gênero Anopheles, em 1897, as conjecturas sobre a transmissão da febre amarela ser feita por meio de um inseto puderam ser vistas como viáveis. 
Neste contexto, a teoria de Finlay voltou ao cenário científico. Em junho de 1900, finda a guerra hispano-americana, a ilha de Cuba se encontrava sob intervenção militar dos EUA. Preocupado com a doença que vinha dizimando seus habitantes, o governo americano enviou uma Comissão de Saúde do Exército para estudar, in loco, a etiologia e profilaxia da doença. Esta acabaria por confirmar as conclusões anteriores do médico local.

Chefiada pelo major médico Walter Reed, a comissão objetivava inicialmente refutar as proposições de Sanarelli, pondo a pique o seu bacilo icteróide, que tinha tido existência confirmada por médicos do Serviço Médico da Marinha Americana. Tal objetivo foi logo alcançado. Algumas experiências bastaram para demonstrar que o bacilo icteróide era um microorganismo de invasão secundária no processo de adoecimento. Feito isto, os médicos voltaram-se para as pesquisas de Finlay, demonstrando em menos de dois meses a veracidade de sua postulação. Rapidamente, a comprovação experimental dos trabalhos de Finlay ganhou status de verdade científica. Em fevereiro de 1901, ela foi apresentada ao Congresso Pan-americano realizado em Havana; simultaneamente era iniciada na cidade uma campanha contra a doença, chefiada pelo major médico americano William Gorgas, com base na etiologia recém-ratificada. Logo a teoria de Finlay ganharia o mundo, sendo novamente testada em experiências realizadas pelo Serviço Sanitário Paulista em 1902. No ano seguinte seria aceita, com reservas, no V Congresso Brasileiro de Medicina e Cirurgia, ocorrido no Rio de Janeiro, transformando-se na base das ações sanitárias de Oswaldo Cruz, levadas a cabo nessa cidade.

Voltemos um pouco em nossa cronologia. Em trabalho recente, Benchimol afirma que, no final do século XIX, aos poucos, as idéias sobre a possibilidade de transmissão de doenças por insetos voadores foram ganhando maior repercussão. A partir do início da década de 1890, a imprensa médica e leiga passou a publicar trabalhos, especulando sobre o papel de insetos na transmissão de diversas doenças. Vistos como transmissores mecânicos de germes, vários insetos - sobretudo as moscas eram tidos como possíveis atores do processo de transmissão. Wilson Gambeta também se volta para esse aspecto, acrescentando que o francês Voillot, em relatório sobre a febre amarela em Santos, apresentado ao seu ministro do comércio e datado de 1893, recomendava que os marinheiros cobrissem seus leitos com mosquiteiros para se protegerem dos insaciáveis mosquitos do porto de Santos. Embora não tenhamos tido acesso a esses textos, nem os autores citados tragam maiores informações sobre o grau de valoração que thes foi conferido, ou apresentem mais claramente seus argumentos, fica a impressão de que naquele momento estava na 
ordem do dia a possibilidade da transmissão de doenças infecciosas por meio de insetos. ${ }^{19}$

Foi justamente para esse aspecto que Pereira Barreto se voltou. Em julho de 1900 ele apresentou à Sociedade um estudo sobre a etiologia da febre amarela, referindo-se à possibilidade do mosquito ser um dos responsáveis por sua transmissão. Este opúsculo tem uma história: já nos referimos ao fato de Pereira Barreto ter escrito uma série de artigos para o Commercio de São Paulo, em 1897, sob o título de Epidemiologia. Naquele momento, o médico Victor Godinho, que ocupava o cargo de inspetor sanitário na cidade de Dois Córregos - mais tarde fundaria, junto com Arthur Mendonça, a Revista Médica de São Paulo - também se voltou para a doença, fazendo publicar artigos no Estado de São Paulo. Seus estudos, posteriormente reunidos num livro, voltavam-se para vários aspectos da doença, criticando Pereira Barreto pela defesa exclusiva da transmissão hídrica. A seu ver, o exclusivismo de Pereira Barreto era absurdo, pois, entre outras formas de transmissão aceitáveis, não se podia esquecer a possibilidade da transmissão culicidiana. O artigo de Godinho tomava por base os trabalhos de Finlay, defendendo a hipótese de que os pernilongos de São Paulo poderiam propagar a doença, tal qual faziam com outros males existentes. ${ }^{20}$ Pereira Barreto não retrucou as idéias do colega, pelo contrário, procurou aproximá-las do seu modo de ver, incorporando-as no artigo de 1900.

$\mathrm{Na}$ comunicação apresentada à Sociedade, com seu rebuscado estilo de filósofo positivista - recheado de exaltações aos rigores do método indutivo que, segundo ele, sustentava sua teoria - propunha que o modelo de transmissão da febre amarela deveria ser o mesmo que o da peste bubônica. O bacilo da peste havia sido identificado, em 1894, por Alexandre Yersin. Quatro anos mais tarde, o médico da marinha francesa Simond, em experiências com pulgas realizadas na Índia, mostrou a possibilidade de disseminação da peste bubônica, de animal a animal, pela picada do inseto. Para Pereira Barreto, as duas doenças deveriam ter um inseto como agente transmissor.

Guiado pelo espírito de indução, Simond, pondo em jogo a experimentação toma pulgas aos ratos doentes e, examinando-lhes o conteúdo intestinal, encontrou o bacilo específico da peste, que inocula em ratos sãos e assim, reproduz o quadro sintomático do mormo levantino. (...) O método de pesquisa empregado por Simond é um modelo da lógica científica. Por que razão não utilizaremos as analogias e não procederemos segundo o mesmo método de raciocínio em relação à febre amarela? Tudo em nosso universo está sujeito a leis fixas e invariáveis. Em ciência não se conhecem ex- 
ceções. (...) O mais inexorável determinismo governa toda a esfera biológica. $^{21}$

Mas Pereira Barreto não estava disposto a abrir mão das suas opiniões anteriores sobre a transmissão hídrica da doença, pois era essa hipótese que ele queria reforçar. Para aproximar as duas visões, ele agora propunha que os surtos epidêmicos se dariam em duas fases. Numa primeira, a epidemia tinha seu surgimento causado por uma forma primária de propagação, a hídrica. A poluição do lençol freático de determinada região era a causa primária do surgimento da doença. Em seguida, o mal passava a contar com diversas formas de disseminação. Entre elas, era de especial importância o papel dos mosquitos. Dizia ele:

Lembremo-nos que os poços são os perenes mananciais em que se formam miríades de legiões de pernilongos. É intuitivo que gerados em águas contaminadas, venham eles à tona com suas trombas carregadas de bacilos específicos. Cada picada será uma certeira inoculação. Aí temos o pendant das pulgas na peste. A crença popular de que a febre amarela se espalha mais à noite do que de dia é perfeitamente fundada; os hábitos nocivos do alado parasita sanguinoso amplamente explicam o incontestado fato. (...)

É inútil, portanto, a hipótese do bolor em simbiose com o bacilo icteróide e dos quais seria o ar o veículo (...). O ar veicula o pernilongo e é este que veicula o bacilo amarílico. E torna-se assim igualmente inútil a hipótese da infecção domiciliar.

De posse destes fatos podemos fazer agora seguras abstrações. (...) A questão do pernilongo reduz-se portanto a uma questão de água. A água afinal é o último elemento irredutível, que resta quando encaramos a questão epidemiológica sob o ponto de vista abstrato. Podemos, por conseqüência, afirmar, em última análise que a febre amarela só se propaga pela água. ${ }^{22}$

Analisando dados do Serviço Sanitário referentes à marcha da epidemia que, naquele momento, reinava na região do Tietê, ele tentava demonstrar sua tese. No primeiro momento, a epidemia obedecia à lei da gravidade: as águas dos poços mais altos contaminavam as dos mais baixos, fazendo a doença descer a colina. No momento seguinte tudo mudava.

No segundo período, pelo contrário, a epidemia não se subordina mais às condições topográficas e ataca a esmo, ora um ora outro quarteirão, ora o alto, ora o baixo. Se a hipótese da intervenção do pernilongo, como fator novo que entra em cena, não explica a chocante contradição, eu quisera que os colegas me indicassem qual a outra hipótese mais plausível que poderemos adotar. ${ }^{23}$ 
O trabalho de Pereira Barreto não gerou novas discussões. Depois dele, mais uma vez o assunto andou um pouco esquecido, só voltando a ganhar força a partir da elaboração das experiências de avaliação da teoria de transmissão culicidiana pelo Serviço Sanitário. Nesse período, a maioria dos trabalhos apresentados na casa se voltava para a terapêutica da doença, alguns deles se centrando na idéia do soro antiofídico ser útil na terapêutica da doença. Como vemos, naquele momento o artigo de Pereira Barreto não foi fecundo nem definitivo. Não gerou novas discussões, nem fez com que seus oponentes passassem a aceitar a transmissão hídrica. Além disso, ele passou despercebido pelos estudiosos do tema. No entanto, dois aspectos fazem com que ele seja de fundamental importância. Vejamos:

Em primeiro lugar, é forçoso reconhecer a sua originalidade. Apesar de termos observado que as idéias sobre transmissão de doenças infecciosas por insetos não eram mais tidas como exóticas, não podemos deixar de assinalar que o trabalho de Pereira Barreto ultrapassava o caráter de uma simples elucubração, tomando por base a observação de dados epidemiológicos de um surto em marcha. Além disso, ele foi escrito antes da já citada comissão americana voltar-se para as experiências com os mosquitos em Cuba. Vejamos as datas. Em 11 de agosto de 1900, foram iniciadas as experiências para a comprovação da teoria de Finlay. No fim daquele mesmo mês, foram obtidos os dois primeiros casos positivos de infecção culicidiana. Entre 25 de setembro e 22 de outubro foi redigida nota preliminar sobre as experiências. Esta foi apresentada na $28^{\underline{a}}$ reunião da American Public Health Association, em Indianápolis, ocorrida entre 22 e 26 de outubro de 1900 (Benchimol, 1999). Pois bem, em 16 de julho - vinte dias antes do começo das experiências -, Pereira Barreto elaborou seu trabalho e apresentou-o à Sociedade.

A precedência do trabalho de Pereira Barreto não teria grande relevância não fosse por outro aspecto: o fato de ele ter sido importante no processo de aceitação da teoria culicidiana, e na sua colocação em prática em ações desempenhadas pelo Serviço Sanitário de São Paulo. Se não, vejamos. Assim que o relatório de Walter Reed, demonstrando a viabilidade da transmissão culiciadiana da doença, foi a público, Emílio Ribas, diretor do Serviço Sanitário, abraçou formalmente a teoria culicidiana. Em janeiro de 1901 ele publicou um opúsculo sobre o mosquito como transmissor da febre amarela. Seu livreto apresentava os pernilongos como únicos transmissores da doença, pregava sua extinção e sugeria medidas para evitar ou controlar epidemias. Apesar do caráter preliminar confesso, o trabalho apresentava-se como uma tomada de posição oficial da Saúde Pública paulista em relação ao problema. Na apresentação, Ribas 
afirmava que as recentes descobertas da comissão chefiada por Walter Redi, em Cuba, animaram-no a escrevê-lo. Em seguida, partia para uma análise retrospectiva de diversas epidemias da doença, que mostrava a viabilidade de terem sido os mosquitos os responsáveis pela sua propagação. Para aumentar o seu poder de fogo, Ribas trouxe à arena um aliado de grande peso: Pereira Barreto. Suas idéias foram inflectidas em direção às conclusões chegadas em Cuba, fortalecendo ainda mais sua posição. Assim, as proposições de Pereira apresentadas à Sociedade foram usadas agora para deslanchar uma luta contra os mosquitos.

Vem a apelo lembrar que o venerando e distinto profissional Dr. Luiz Pereira Barreto em uma interessante e patriótica conferência sobre a epidemia do Tietê, realizada na noite de 16 de julho de 1900 na Sociedade de Medicina e Cirurgia desta Capital, deu importante papel ao pernilongo como veículo e agente inoculador do gérmen da febre amarela.

O eminente e responsável médico considerou esses insetos como um dos principais elementos de propagação da moléstia. Enfim, o Dr. Pereira Barreto, fervoroso adepto da doutrina hídrica, apenas diverge no particular da comissão norte-americana quando diz: o pernilongo é um fator importante mas só é exclusivamente pelo fato de provir de uma água contaminada.

Destarte ainda fica de pé a necessidade da extinção dos mosquitos, como excelente meio profilático, mesmo para aqueles que na questão da febre amarela pensam como o dr. Barreto e o Professor Camilo Terni. ${ }^{24}$

Para fortalecer ainda mais sua posição, Ribas fez uso dos conhecimentos de outro aliado, Adolpho Lutz. Toda a segunda parte de seu trabalho era baseada em uma nota, ainda inédita, de Lutz, voltada para a identificação dos mosquitos que poderiam transmitir a febre amarela ( $c u$ lex taeniatus e culex fatigans). Nela, Lutz apresentava os prováveis vilões, mostrava suas características morfológicas e hábitos. Com o seu rigor característico, ele ainda hesitava em dar uma opinião final sobre a questão, apenas indicando possibilidades. A título de ilustração, vale citar um pedacinho do texto atribuído por Ribas a Lutz. É interessante notar que Lutz pensa a febre amarela de acordo com o modelo da infeção parasitária:

Assim fica explicado como esses insetos podem transmitir certas moléstias, como o paludismo e a filariose cujos organismos causadores tem de passar no corpo do mosquito umas fases da evolução que mesmo em tempo de calor ocupam uma série de dias e em tempo de frio quase não progridem. A febre amarela provavelmente obedece as mesmas condições de modo que a infecção só pode dar-se depois de um certo número de dias, o que explica 
o intervalo muitas vezes observado entre o caso causador e os casos subseqüentes de uma epidemia e que não pode ocorrer por conta da incubação geralmente muito curta na febre amarela. ${ }^{25}$

O livreto de Ribas foi o primeiro passo do epílogo da história das grandes epidemias de febre amarela no Estado de São Paulo. Logo após a sua publicação, acompanhado por Lutz, ele se empenhou fortemente em criar condições para refazer as experiências realizadas em Cuba, com o fito de ratificar a teoria. Rapidamente, ele conseguiu mobilizar as equipes do Instituto Bacteriológico e do Hospital de Isolamento, e obteve a aprovação do presidente do Estado, Rodrigues Alves, para utilizar voluntários humanos em suas pesquisas. Suas experiências foram realizadas no Hospital de Isolamento da cidade em duas etapas. A primeira deu-se entre dezembro de 1902 e janeiro de 1903; a segunda, entre abril e maio de 1903. Várias questões técnicas foram responsáveis pela demora na execução das experiências, que foi por todo o tempo acompanhada por uma comissão de médicos especialmente escolhidos para esse fim. Presidida pelo próprio Pereira Barreto, era também composta por Silva Rodrigues e Adriano de Barros. Seu relatório final concluía que as experiências realizadas provavam que a febre amarela não era contagiosa, e que o único vetor de transmissão da doença era o mosquito. O opúsculo, que tinha Pereira Barreto como primeiro autor, e era dirigido a Emílio Ribas, é uma jóia reveladora da total adesão do antigo defensor da transmissão hídrica à teoria dos mosquitos. Além disso, mostra o engajamento de seu autor na colocação em prática de medidas de saúde pública exclusivamente voltadas para o combate ao mosquito. Vejamos um pouco de suas conclusões:

(...) É completamente infundada a crença na transmissão da febre amarela pelos fomites. Qualquer que seja o gérmen dessa moléstia esse gérmen perde a faculdade germinativa todas as vezes que não encontra as condições favoráveis do seu meio natural. As experiências (...) demonstram que só no organismo do mosquito encontra o gérmen amarílico as condições necessárias para a sua evolução.(...) Afirmar sem provas a multiplicidade dos meios de propagação da febre amarela é simplesmente introduzir o regime intelectual do politeísmo no domínio atual da medicina.

(...) Uma vez que a febre amarela não é contagiosa, sendo mesmo de todo impossível a sua transmissão pelos objetos que estiveram em contato com o doente, é evidente que o sistema de polícia sanitária até aqui usado, sob a pressão da crença em sua contagiosidade, deverá ser radicalmente modificado. Cada doente deve permanecer em sua casa, com a condição apenas de ficar protegido contra a picada dos mosquitos, o que é facílimo con- 
seguir-se mediante um simples cortinado, enquanto no resto da casa se dá a caça direta ao stegomia. Imenso passo este sob o ponto de vista da liberdade dos cidadãos! Conquista incomparável quanto ao bem estar dos doentes e ao sossego das famílias!

Ao lado da ciência pura ergue-se para a humanidade um vasto repositório de aplicações práticas imediatas e das quais o nosso próprio país vai ser o primeiro a se beneficiar. (...) Vós precisais agir com firmeza, e não podeis pautar a vossa norma de conduta se não assentando-a resolutamente sobre a ciência dos nossos dias. É só dirigindo insistentemente os vossos mais enérgicos meios de ação direta e indiretamente contra o stegomya fasciata que conseguireis lavar do corpo do Estado de São Paulo da negra mácula que o desfigura e desonra, ameaçando sustar toda a sua evolução econômi$\mathrm{ca.}^{26}$

Os conselhos de Barreto foram ouvidos. Antes mesmo da apresentação do resultado das experiências com os mosquitos, Ribas já vinha colocando em prática sua hipótese de trabalho. Desde 1901, as comissões sanitárias que atuavam em Sorocaba uniram aos seus inimigos os mosquitos, procurando dar fim às águas estagnadas que pudessem facilitar o seu aparecimento. Em 1902, o mesmo se deu na cidade de São Simão e, no ano seguinte, o próprio Ribas comandou a destruição dos focos de mosquitos, como medida principal de profilaxia. Todas essas cidades acabaram, em pouco tempo, livres da febre amarela.

Em 1903, no V Congresso Brasileiro de Medicina e Cirurgia, reunido no Rio de Janeiro, foram postas em votação as conclusões sobre as experiências havidas em São Paulo. Em plenária presidida por Oswaldo Cruz, o congresso reafirmou que a teoria da transmissão da febre amarela pelo stegomya fasciata era fundada em observações e experiências de acordo com os métodos científicos, e que nenhum outro modo de transmissão estava demonstrado rigorosamente. $\mathrm{Na}$ verdade, a resolução final do congresso também procurava se esquivar da aceitação da exclusividade da teoria culicidiana, procurando, através de eufemismos, permitir a comprovação futura de novas formas de transmissão. De qualquer forma, estava aberto o caminho para o surgimento de grandes campanhas sanitárias contra a doença, embasadas na destruição dos mosquitos e de suas larvas.

\section{CONCLUSÃO}

O longo caminho das discussões sobre a febre amarela na Sociedade de Medicina e Cirurgia de São Paulo nos mostra alguns aspectos bastante interessantes. $\mathrm{O}$ primeiro a que vou me reportar diz respeito à relação entre as discussões sobre a doença e o surgimento das epidemias no Esta- 
do. Como vimos, nos momentos em que a discussão mais aflorou no plenário, estavam acontecendo, ou tinham acontecido epidemias nas cidades mais importantes do Estado, como Campinas e Santos. Parece óbvio que o surgimento de epidemias nas cidades gerasse discussões na Sociedade, mas essa vinculação mostra também a sintonia da instituição com as principais questões médicas de seu tempo. Não se tratava, como algumas vezes acusavam os jornais da época, de "discussões estéreis e etéreas", mas sim da busca da compreensão e contribuição na resolução de problemas de saúde que afetavam o Estado.

Apesar disto, observamos que a forma de atuação institucional diante desses problemas era bastante ambígua. Por um lado, a Sociedade, através de alguns de seus mais importantes sócios, tinha acesso direto a fóruns de decisão política, muitas vezes conseguindo colocar à frente seus projetos, através da influência política individual de seus membros. Vimos isso em relação às práticas de saneamento efetuadas pelo governo estadual a partir de 1898, quando Pereira Barreto foi perdendo terreno na discussão sobre a transmissão hídrica da doença, mas acabou influenciando a forma de combatê-la. Nesse momento, fica patente a influência do ex-presidente da Sociedade (seu mandato acabara em março de 1896) nos rumos da saúde pública do Estado. No entanto, não podemos simplificar a questão em busca de uma afirmação do nível de ascendência institucional da Sociedade na atuação da saúde pública estadual. Isto porque Pereira Barreto não pode ser visto somente como um dos líderes da Sociedade de Medicina e Cirurgia de São Paulo, seu prestígio pessoal como político, médico e intelectual fazia com que suas postulações fossem respeitadas não só pela sua autoridade no campo médico.

Por outro lado, a incapacidade da Sociedade em obter um consenso entre seus membros, sobre uma questão que influiria diretamente na ação do governo a ser posta em prática, impediu uma atuação consultiva da instituição perante a atuação governamental. Além disso, ela não se envolveu nas discussões do projeto no Legislativo, apesar de seu vice-presidente nessa época, Miranda de Azevedo, ter tido uma atuação política destacada nas discussões. No debate ocorrido no Legislativo, ele não apresentou nenhuma proposição ou emenda ao projeto, sua atuação foi no sentido de procurar, de todas as formas, retardar ao máximo o seu andamento, recurso usual da minoritária bancada oposicionista, que não tinha outra forma de defender seus interesses. ${ }^{27}$

Acreditamos que a omissão se insere no quadro mais amplo - e momentâneo - de desinteresse da recém-fundada Sociedade de proceder a uma atuação institucional mais ativa em relação aos rumos da saúde pública no Estado. Falta de consenso sobre decisões técnico-científicas a se- 
rem tomadas, diversidade de interesses políticos, disputa por interesses locais; ainda não podemos precisar quais os motivos que a impediam de participar institucionalmente dos debates acerca das transformações da saúde pública, fazendo com que sua atuação se limitasse a iniciativas pessoais de seus sócios. Evitamos encaminhar nossa análise no mesmo sentido da elaborada por Maria Alice Ribeiro, que acredita que a Sociedade era quase uma extensão do Serviço Sanitário, uma espécie de braço acadêmico da saúde pública, pronta para ratificar suas doutrinas e colaborar com suas ações. ${ }^{28}$ No nosso entender, este tipo de atuação foi episódico, pois, em outros momentos, a Sociedade emitiu pareceres e projetos sobre a saúde paulista, muitas vezes contrários à orientação dos serviços oficiais de saúde. Poucos anos depois do período em foco, 1904, a Sociedade elaboraria parecer contrário ao Serviço Sanitário, em relação à utilização doméstica das águas do rio Tietê. Em artigo recentemente publicado, também apresento uma controvérsia científica havida entre membros da Sociedade e o diretor do Serviço Sanitário em relação à identificação de uma doença ocorrida nos idos de $1910 .^{29}$

Por fim, não podemos deixar de fazer menção ao legado da Sociedade no processo de aceitação da teoria culicidiana da febre amarela no país. Até pouco tempo, a atuação dos paulistas na história da luta contra a 240 doença foi relegada, graças às campanhas de combate perpetradas por Oswaldo Cruz no Rio de Janeiro. Hoje, novos trabalhos, como os de Benchimol e Almeida, mostram que a iniciativa carioca fecundou um solo já adubado pelos estudos dos médicos paulistas. No período que se estende entre o início da década de 1990 e a fundação do Instituto Oswaldo Cruz, os trabalhos de verificação de experimentos de identificação do micróbio da doença e de hipóteses sobre sua forma de transmissão transformaram o grupo de pesquisadores do Instituto Bacteriológico em autoridades nas questões referentes à febre amarela. ${ }^{30}$ Foi esse capital científico que possibilitou o salto em direção à retomada das experiências dos cubanos por Ribas e Lutz e, a partir delas, às medidas de saneamento pioneiras que englobavam a destruição dos focos de mosquitos no Estado, e a defesa intransigente da teoria da transmissão culicidiana da doença no V Congresso Brasileiro de Medicina e Cirurgia realizado no Rio de Janeiro em 1903.

O que para nós mostra-se importante é reafirmar o pertencimento da Sociedade a esse grupo, e a importância dos trabalhos lá apresentados no processo de disseminação da nova teoria. Não foi sem motivo que, ao apresentar sua tomada de posição pública sobre o problema, Ribas tomou por base os trabalhos de Pereira Barreto e de Lutz - utilizando o primeiro aliado novamente como presidente da comissão de verificação 
das novas experiências. Independentemente de suas posições anteriores em relação à transmissão da doença, a citação de seus trabalhos, além de demonstrar a autoridade científica destes dois personagens no campo médico paulista, mostra que o processo de aceitação da nova teoria foi um trabalho coletivo, no qual se somaram as convicções de Ribas as postulações epidemiológicas de Pereira Barreto e os conhecimentos entomológicos de Adolpho Lutz. Foi a complementaridade desses diversos estudos que, em última análise, deu o respaldo às ações postas em prática no Estado, que conseguiram debelar a doença antes mesmo de obter consenso sobre a sua forma de veiculação.

\section{NOTAS}

${ }^{1}$ BENCHIMOL, Jaime L. Dos micróbios aos mosquitos: febre amarela e revolução pasteuriana no Brasil. Rio de Janeiro: Editora Fiocruz / Editora da UFRJ, 1999.

${ }^{2}$ ALMEIDA, Marta de. República dos invisíveis: Emilio Ribas, microbiologia, e saúde pública em São Paulo 1898-1917. Dissertação de mestrado apresentada ao Departamento de História da FFLHC da Universidade de São Paulo, 1998, e ALMEIDA, Marta de. Combates sanitários e embates científicos: Emílio Ribas e a febre amarela em São Paulo. História, Ciência, Saúde - Manguinhos. Rio de Janeiro, Vol. VI, n. 3, novembro-fevereiro 2000, p.589.

${ }^{3}$ BOURDIEU, Pierre. O campo científico. In: ORTIZ, R. (org) Sociologia. São Paulo: Ática, 1983, pp.123-155.

${ }^{4}$ FRANCO, Odair. História da febre amarela no Brasil. Rio de Janeiro: Ministério da Saúde. Departamento de Endemias Rurais, 1969.

${ }^{5}$ RIBEIRO, Maria Alice Rosa. História sem Fim... um inventário da saúde pública. São Paulo: UNESP, 1993.

${ }^{6}$ BENCHIMOL, Jaime L. Op. cit.

${ }^{7}$ ALMEIDA NETO, Joaquim Caetano, e LEITE, Maurício Sérgio Brasil. Febre amarela. In: VERONESI, R. (org.). Doenças infecciosas e parasitárias. Rio de Janeiro: Guanabara Koogan, 1991, pp.163-71.

${ }^{8}$ TEIXEIRA, Luiz Antonio. Ciência e saúde na terra dos bandeirantes: a trajetória do Instituto Pasteur de São Paulo no perído de 1903-1916. Rio de Janeiro: Editora da Fiocruz, 1995.

${ }^{9}$ PEREIRA BARRETO, Luiz. Moção a propósito das epidemias de febre amarela. Boletim da Sociedade de Medicina e Cirurgia de São Paulo. Ano I, n.9, março de 1896, pp. 1-3.

${ }^{10}$ MAGALHÃES, Bernardo. Epidemiologia. O Estado de S. Paulo, 9, 11, 13 de maio de 1896, p.1.

${ }^{11}$ Repositório de fatos. Boletim da Sociedade de Medicina e Cirurgia de São Paulo. Ano I, n.11, maio de 1896, p.17.

${ }^{12}$ TELAROLLI JUNIOR, Rodolpho. Poder e saúde: as epidemias e a formação dos serviços de saúde em São Paulo. São Paulo: Unesp, 1996, p.104.

${ }^{13}$ BENCHIMOL, Jaime. Op. cit. 
${ }^{14}$ LUTZ, Adolpho. Relatório acerca de um micróbio da febre amarela em Montevidéu. Boletim da Sociedade de Medicina e Cirurgia de São Paulo, ano III, n. 29, novembro de 1897, p.30.

${ }^{15}$ MEIRA, Sérgio. Sanarelli em São Paulo. Boletim da Sociedade de Medicina e Cirurgia de São Paulo, ano III, n. 30, dezembro de 1897, pp. 3-4.

${ }^{16}$ MENDONÇA, Arthur. Pesquisa do bacilo icteróide em São Carlos do Pinhal. Revista Médica de São Paulo. Ano I, n. 5, junho 1898, pp. 84-85.

${ }^{17}$ AZEVEDO, Affonso. 1902. A febre amarela e sua propagação pelos mosquitos. Revista Médica de São Paulo. Ano V, n. 19, outubro de 1902, pp. 390-392.

${ }^{18}$ BENCHIMOL, J. Op. cit.

${ }^{19}$ BENCHIMOL, J. A instituição da microbiologia e a história da saúde pública no Brasil”. Ciência e saúde coletiva. Associação Brasileira de Pós-Graduação em Saúde Coletiva. V.5, n.2, p. 274; GAMBETA, Wilson. Soldados da saúde: a formação dos serviços de saúde pública em São Paulo, 1889-1918. Dissertação de mestrado apresentada à FFCH/USP, 1988, p. 64;. e Voillot, $A$. La fievre jaune au Bresil et en particulier a Santos; rapport presente a M. Le Ministre. Gray Bouffaut Fréres, 1895, p.8, apud GAMBETA, op. cit. p. 64.

${ }^{20}$ GODINHO, Victor. A febre amarela no Estado de São Paulo, patogenia, transmissibilidade, tratamento racional. São Paulo: Typ. Salesiana, 1987.

${ }^{21}$ PEREIRA BARRETO, Luiz. Epidemiologia: a lógica como instrumento de pesquisa. Revista Médica de São Paulo. Ano III, n. 8, agosto de 1900, pp. 197-204.

${ }^{22}$ Idem.

${ }^{23}$ Idem.

${ }^{24}$ RIBAS, Emílio. 0 mosquito como agente da propagação da febre amarela. São Paulo: Tipografia do Diário Oficial, 1901.

${ }^{25} \mathrm{Idem}$.

${ }^{26}$ PEREIRA BARRETO. Segunda série de experiências sobre o contágio da febre amarela. Revista Médica de São Paulo. Ano 6, n. 5, junho 1903, pp. 278-281"

${ }^{27}$ TELLAROLI JUNIOR, op. cit., p.217.

${ }^{28}$ RIBEIRO, Maria Alice Rosa. Op. cit.

${ }^{29}$ TEIXEIRA, Luiz Antonio. Alastrim Varíola é. História, Ciência, Saúde - Manguinhos. Rio de Janeiro, vol. VII, n. 1, março - junho 2000, pp. 47-72.

${ }^{30}$ BENCHIMOL, J. 1999, op. cit., p.353. 